Ann. Biol. anim. Bioch. Biophys., 1979, 19 (1B), 225-234.

\title{
Ovine prenatal growth, its mathematical description and the effects of maternal nutrition
}

\author{
par J. J. ROBINSON, I. MCDONALD
}

Roweff Research Instifute, Bucksburn, Aberdeen $A B 2$ 9SB (Scotland).

\begin{abstract}
Summary. Comparisons are made among eight different types of equation that have been used to describe the growth of the sheep foetus in the last 12 weeks of gestation. The Gompertz equation is preferred to the others because it provides sensible estimates on extrapolation to 25 days after mating and its parameters can be interpreted in simple biological terms. A standardised form of the Gompertz equation can be employed in comparing fotal growth patterns between species.

Reviews are presented of the literature on the effects of maternal nutrition on foetal growth in early, middle and late pregnancy respectively, and the findings are discussed in relation to estimates of foetal weight and specific growth rate at each stage, derived from a Gompertz equation fitted to foetal data.

The lack of a satisfactory model for foetal development has contributed to disagreement on whether maternal under-nutrition has different effects on different foetal organs and tissues. It is concluded that there are differential effects and that a recent extension of the Gompertz equation to embrace the allometric relationship provides a clearer and more generally applicable model for describing the growth of foetal constituents than does the allometric equation by itself.
\end{abstract}

\section{Introduction.}

Mathematical equations are of very limited value as a substitute for basic biological data unless they can satisfy at least three conditions. (i) They should agree with the data, subject only to limitations imposed by the variability of the latter. (ii) They should yield tenable extrapolations outside the range of the data. (iii) It should be possible to interpret the parameters of the equation in simple biological terms.

Many published equations describing pre-natal growth are concerned only to satisfy the first of these conditions, and can do liffle more than provide convenient descriptions of the data. When all three conditions are satisfied, however, the equation can be a powerful aid to the identification and interpretation of differences from one set of data to another, and can more safely be incorporated into models of growth and production involving the whole reproductive cycle (e. g. Graham et al., 1976). In the present paper we compare a number of equations that have been used to describe prenatal growth in sheep, we review the evidence on the modifying effects of maternal nutrition on foetal development and we discuss some of these effects in the light of the preferred equations. 


\section{Equations relating foetal weight to time from conception.}

Nearly all the published data on foetal growth in sheep have been confined to the final 12 out of the total 21 weeks of gestation, and so it has been possible to fit a great variety of equations, some of which are shown in table 1 . The extrapolative capabilities of each equation, used with the values of the constants as given in the original publication, have been tested by using it to estimate the weight of a foetus at 25 days from conception. On the basis of a review of the literature (Robinson et al., 1977), and of additional observations (Rhind and Robinson, unpublished data), this weight is of the order of $0.25 \mathrm{~g}$. The estimates from the equations in table 1 were respectively 273 , - 5.5, 0.36, 3.7, 1.6, 0.29, 0.33 and - $102 \mathrm{~g}$. Apart from the Gompertz equations, only the "self-adjusting power law » gave an estimate of the correct order of magnifude.

TABLE 1

Equations that have been to relate foetal weight $(y)$ to foetal age (t)

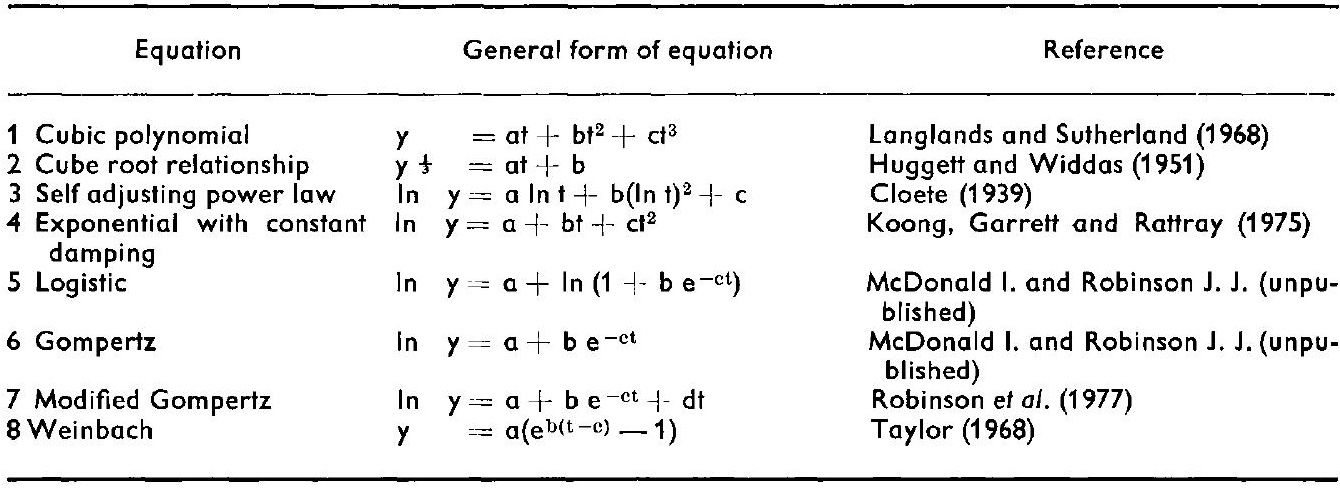

A further comparison of the extrapolative qualities of the equations is given in figure 1 , which shows how the estimated specific growth rate, $\frac{1}{y} \frac{d y}{d t}$, varies with $t$, the foetal age. It is generally accepted that specific growth decreases at a decreasing rate with increasing gestational age. Except for the Gompertz equation, which has by definition an exponentially decreasing specific growth rate, only the self-adjusting power law exhibits a curve of even approximately the correct shape over the whole of gestation, and the latter is anomalous in the very early stages in that the specific growth rate tends to infinity as gestational age decreases towards zero.

Although the self-adjusting power law satisfies the first and second of our criteria for a growth equation almost as well as does the Gompertz, it is inferior by the third criterion, in that there is no simple biological interpretation for the values of the parameters $a, b$ and $c$. Those for the Gompertz equation have such an interpretation, as has been described by Laird, Tyler and Barton (1965), Laird (1966), and Robinson et al. (1977), and we may therefore argue that the Gompertz equation is likely to be more useful in the analysis of growth data than any of the other equations examined. One 
relatively little known transformation of the equation can be used to set the ovine prenatal growth pattern in the context of that for other species.

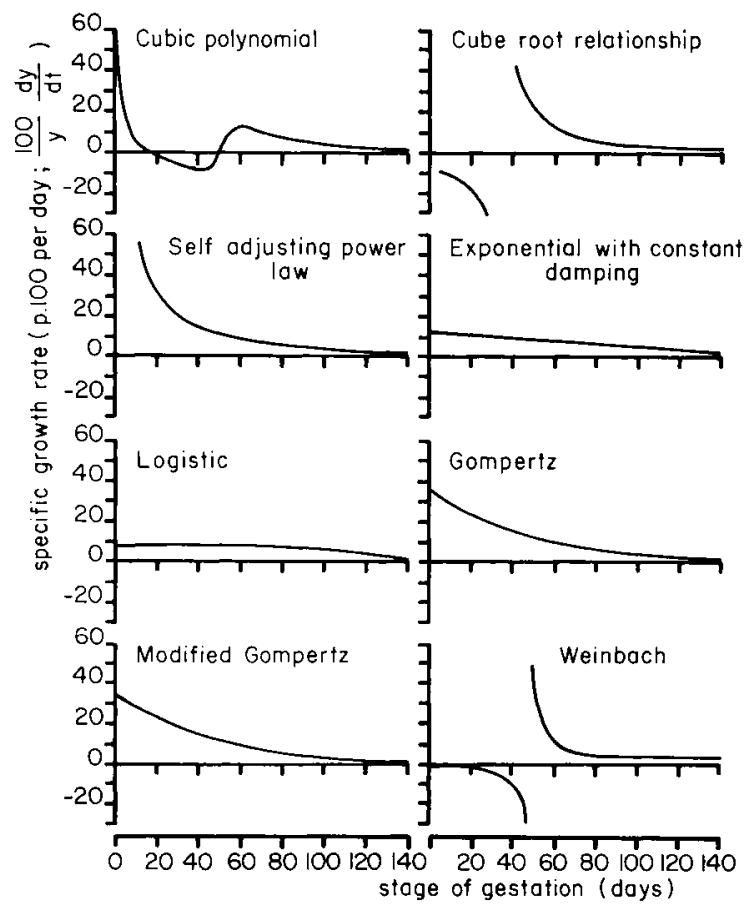

FIG. 1. - Specific growth rates estimated throughout gestation from a range of equations that have been fitted to data obtained during the last 12 weeks of gestation.

TABLE 2

The timing of conception $\left(T_{c}\right)$ and birth $\left(T_{b}\right)$ for a range of mammalian species on the transformed time scale employed in describing their foetal growth patterns by the standardised Gompertz equation

\begin{tabular}{llrr}
\hline \multicolumn{1}{c}{ Species } & \multicolumn{1}{c}{ Source } & $T_{c}$ & $T_{b}$ \\
\hline Mouse & Laird (1966) & -7.0 & -0.8 \\
Rat & $-\quad-$ & -6.3 & -2.5 \\
Guinea pig & Nelson and Cooper (1975) & -5.9 & 0.4 \\
Cat & Laird (1966) & -6.3 & 0.8 \\
Sheep & McDonald I. and Robinson J. J. (unpublished) & -5.3 & 0.2 \\
Human & Laird (1966) & -5.4 & 0.2 \\
Pig & McDonald I. and Elsley F.W. H. (unpublished) & -5.2 & 2.3 \\
Cattle & Laird (1966) & -5.4 & 0.4 \\
& & & \\
\hline
\end{tabular}


As described by Laird (1966), there is a standard form of the Gompertz equation which can provide a useful basis for comparisons of foetal growth patterns both within and between species. By linear transformations of both axes, the equation

$$
\ln y=a+b e^{-c t}
$$

can be changed to the standard form $\ln Y=-\mathrm{e}^{-0,5266 \mathrm{~T}}$. In terms of the transformed weight and time scales, all Gompertz data then fall on a single growth curve. In the new weight scale, $Y$, each foetal weight is expressed as a fraction of the asymptotic value. The time scale is determined by two points $; T=0$ corresponds to the time of maximum foetal growth rate, and $T=-1$ corresponds to the time at which foetal weight is half of that at $T=0$. (Values of $Y$ are respectively 0.368 and 0.184 .) There is a considerable degree of agreement between species in the values of $T$ which correspond to the events of conception and birth, as can be seen in table 2, in which we have combined results given by Laird (1966) and more recent measurements.

\section{Nutrition and early foetal growth.}

The tiny absolute foetal growth rates in very early pregnancy would appear unlikely to be vulnerable to changes in the nutrition of the ewe and any effects of nutritional change on subsequent birth weight, such as those shown by Speedy, Black and Fitzsimons (1978), are likely to be indirect and mediated by effects on body condition. Conversely, specific growth rates are very high (16 p. 100 per day even as late as day 40 ) and may make the embryo vulnerable to any sudden stress. Most nutritional studies have focussed attention on survival rather than on growth and it has been suggested that embryo losses are accentuated by poor body condition, by increased duration of under-feeding and also by over-feeding during the pre-implantation phase. Edey (1976) reviewed the results and concluded that nutritionally induced losses seldom exceed 15 p. 100.

There is increasing evidence to suggest that during the period 0 to 16 days the growth of the embryo is influenced by endocrine factors, in particular the circulating levels of blood progesterone (Wintenberger-Torrès, 1967 ; Lawson, 1977), and that these may operate through an alteration in the amino-acid balance of the uterine fluid (Ménézo and Wintenberger-Torrès, 1976). Whether or not these endocrine changes can be linked directly to nutrition or nutritionally imposed stress giving rise to enhanced adrenal activity (Doney, Smith and Gunn, 1976) remains to be proved.

There have been few attempts at direct measurement of effects of early maternal nutrition on foetal weight. Hulet, Foote and Price (1969) did not detect any difference in foetal weight at 21 or 30 days between ewes offered 75 p. 100 and others offered 150 p. 100 of their maintenance energy requirements from conception onwards. Similarly, El-Sheikh et al. (1955) and Foote et al. (1959) found no effect of plane of nutrition on foetal weight or crown-rump length at 40 days, although there was an effect on chorion weight.

\section{Nutrition during the second and third months of pregnancy.}

By the end of this period the specific growth rate of the foetus has fallen to under 6 p. 100 per day. Although absolute growth rates are beginning to increase rapidly, the 
foetal weight is still only about 15 p. 100 of that at birth some 8 weeks later. These figures would appear to justify the common husbandry practice of restricting food intake in this mid-pregnancy period to a maintenance level for ewes in good body condition at time of mating. From a review of the literature, Robinson (1977) concluded that the foetuses of young growing ewes or of ewes in poor condition at mating were the most vulnerable to maternal under-nutrition at this stage. It has also been noted that foetuses which are under weight at 90 days are usually associated with placentas which are under weight to an even greater extent. Whether or not high-plane feeding in later pregnancy can wholly compensate for the earlier deficiency is by no means clear (Everitt, 1966, 1967), but the degree of compensation may well be limited by ceilings to the rates at which specific dietary nutrients can cross the placenta (Twardock, Symonds and Sansom, 1971).

\section{Nutrition during the last eight weeks of pregnancy.}

This is the period in which the foetus makes the greatest demands upon the ewe. Specific growth rate is still diminishing, but not as quickly as before, and the maximum absolute growth rate is achieved. The foetal weights reached at 6,4 and 2 weeks prepartum are approximately 30,50 and 75 p. 100 of birth weight. It is sometimes difficult, particularly with multiple foetuses, to raise the level of feed intake in line with these increased requirements, but there is much evidence to show that a considerable degree of maternal under-nutrition can occur before there is any significant depression in foetal growth. Clearly the ewe is able to make good some deficits from her own body reserves, and the level of these reserves at mid-pregnancy is crucial. The general nature of the relationship between maternal nutrition and foetal growth as measured by lamb birth-weight is indicated by figure 2, in which published results from a number

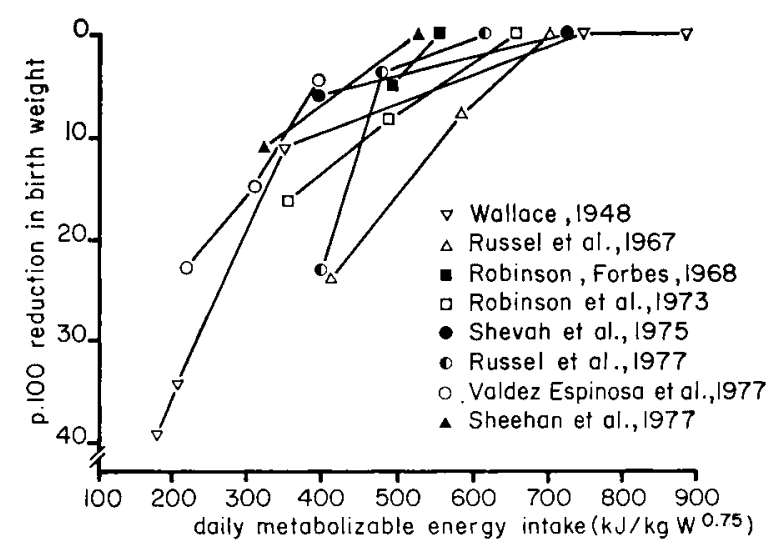

FIG. 2. - The effect of maternal nutrition on lamb birth weight.

of sources have been placed on a common basis for comparison. There is considerable variation in the level of under-nutrition at which birth weight is seriously affected. A recent review (Robinson, 1977) has linked this variation to differences in genotype 
and in body fat reserves and to the effects of deficiencies in specific nutrients, such as protein.

Although birth-weight is easily obtained and is possibly the most important measure of a successful feeding regime, it gives no information on how the preceding pattern of pre-natal growth has been affected by changes in nutrition. Direct observations have been published from only two sequential slaughter experiments. Rattray et al. (1974) fed ewes bearing single and twin lambs at levels 50 p. 100 and 100 p. 100 above maintenance from day 70 , and slaughtered them at intervals up to term. Foetal weight was affected, and the difference increased to approximately 10 p. 100 at term. On the higher level of feeding foetal growth gave no sign of the slight deceleration commonly found in very late pregnancy, whereas foetal growth appeared to flatten off on the lower level, particularly for twin foetuses. Robinson ef al. (1977) concluded that foetal growth was not directly affected by the difference between the two feeding levels included in their study. Although a slight difference (about 4 p. 100) was detected in foetal weight, other evidence suggested that this could be interpreted as a residual effect of corresponding differences in feeding level in earlier pregnancies.

\section{Nutrition and the composition of the foetus.}

In assessing how maternal under-nutrition may affect the functional competence and hence the viability of the new-born lamb it is important to know how it affects the

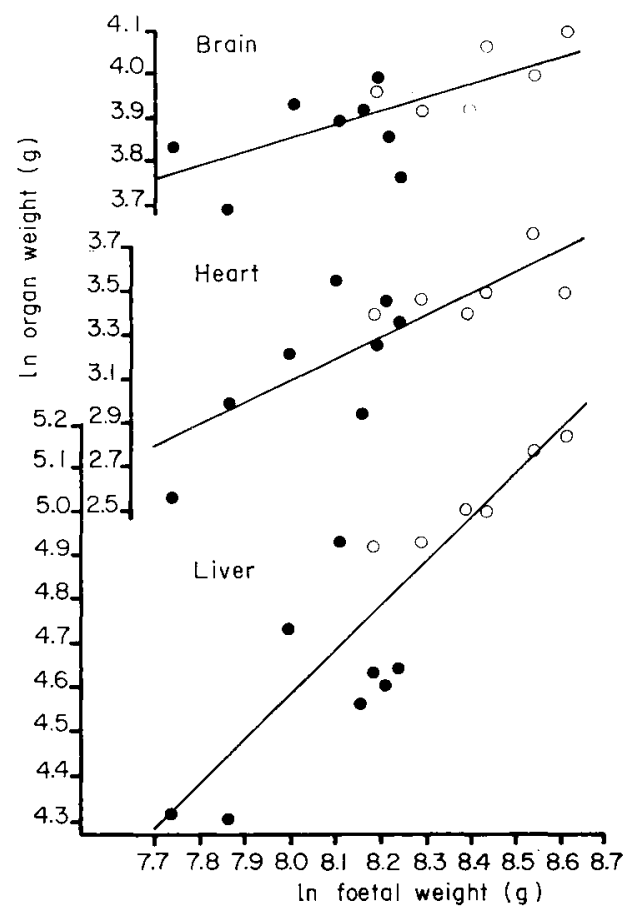

FIG. 3. - Allometric plots for the brain, heart and liver of control (o) and undernourished ( $\bullet$ ) foetuses at approximately 139 days of gestation. [Data source : Creasy et al., 1972]. 
development of individual foetal tissues and organs. There have been conflicting views on whether or not there are differential effects on development (Robinson, 1977), and these have been made more difficult to resolve by differences in the definition of differential effects.

Some authors have adopted the simple approach of comparing the ratios of organ and tissue weights to total la mb weights at birth, between lambs from control and undernourished ewes. For example, Creasy et al. (1972) show that under-nutrition produces a higher ratio for weight of brain but a lower ratio for weight of liver. This is conclusive as regards the nature of the end product but uninformative as regards the development process itself.

Other authors would deny that results such as these demonstrate differential growth and would suggest instead that the lambs from the under-nourished ewes were different in composition because they were lighter. They were developing along exactly the same path as the control lambs but had made less progress along that path at time of birth. It is argued that because of allometric relationships between the total weight of the foetus and component weights, the ratio of the part to the whole inevitably changes with growth. This argument might be supported by allometric plots (fig. 3 ) of the data of Creasy ef al. (1972), for example, which indicate that the individual lambs from both treatment groups can be treated as a single population and fitted by a common allometric equation. The general consensus of recent opinion has accepted this view both for sheep and for other species (e. g. Everitt, 1968 ; Fowler and Livingstone, 1972).

While much of the difference in composition at birth may well arise because the under-nourished lamb is lighter and at an earlier stage of development, we consider that there is good reason to doubt that this is entirely true and to question whether the light lamb at birth can be equated exactly with a younger foetus of the same weight. As

\section{TABLE 3}

Estimates of allometric coefficients relating organ weights to total foetal weights for lamb foetuses whose weight varied because of varying nutrition (partial coefficients) or becouse of varying foetal age (total coefficients).

\begin{tabular}{|c|c|c|c|c|}
\hline & \multicolumn{4}{|c|}{ Estimated allometric coefficients } \\
\hline & (Partial) & (Partial) & (Total) & (Total) \\
\hline \multicolumn{5}{|l|}{ Organ } \\
\hline $\begin{array}{l}\text { Brain } \ldots \ldots \ldots \ldots \ldots \\
\text { Heart } \ldots \ldots \ldots \ldots \ldots \\
\text { Liver } \ldots \ldots \ldots \ldots \ldots \\
\text { Kidney } \ldots \ldots \ldots \ldots \\
\text { Digestive tract ..... }\end{array}$ & $\begin{array}{l}0,32 \\
1.01 \\
0.99 \\
0.13 \\
0.92\end{array}$ & $\begin{array}{l}0.32 \\
0.85 \\
1.22 \\
- \\
-\end{array}$ & $\begin{array}{l}0.58 \\
0.97 \\
0.39 \\
0.65 \\
1.15\end{array}$ & $\begin{array}{l}0.59 \\
0.93 \\
0.54 \\
0.66 \\
1.04\end{array}$ \\
\hline Source of data & $\begin{array}{c}\text { Creasy et } a l . \\
(1972)\end{array}$ & $\begin{array}{c}\text { Alexander } \\
(1974)\end{array}$ & $\begin{array}{c}\text { Thurley ef al. } \\
\text { (1973) }\end{array}$ & $\begin{array}{c}\text { Richardson } \\
\text { and } \\
\text { Hebert (1978) }\end{array}$ \\
\hline $\begin{array}{l}\text { Foetal weights }(\mathrm{kg}) \\
\text { Foetal ages (days).. } \\
\text { Basis of estimates .. }\end{array}$ & $\begin{array}{l}2.3 \text { to } 5.5 \\
137-141 \\
\text { Data }\end{array}$ & $\begin{array}{c}2 \text { to } 4 \\
\text { new born } \\
\text { Diagrams }\end{array}$ & $\begin{array}{c}2 \text { to } 4 \\
113-136 \\
\text { Equations }\end{array}$ & $\begin{array}{c}2 \text { to } 4 \\
113-134 \\
\text { Equations }\end{array}$ \\
\hline
\end{tabular}


the argument against differences has been based on the allometric relationship, we will use allometric coefficients calculated in two different ways to suggest that there are some discrepancies. The first two columns of coefficients in Table 3 may be called " partial » coefficients as they are calculated from foetuses at a fixed age (term) whose variation in weight stems from various forms of growth retardation. The second two columns are «total» coefficients and were obtained from normal foetuses covering similar ranges of foetal weight to the first two sets but measured over a range of three weeks in foetal age. The coefficients in table 3 have been estimated from published equations or diagrams or else calculated directly from the individual data where these have been published. For brain weight it appears that the partial coefficients are smaller than the tolal ones, whereas the opposite is true for the weight of the liver. This would suggest that there are genuine differential effects, agreeing qualitatively although not necessarily quantitatively with the differences in weight ratios at birth reported by Creasy et al. (1972).

There are limitations to the capacity of the allometric model to describe the growth process in detail, even when a distinction is made between the total and partial coefficients. It would appear preferable to discuss nutrifional effects in relation to a mathematical model making explicit allowance for foetal age as well as for foetal weight. Such a model has been proposed by McDonald, Wenham and Robinson (1977), and used in assessing the effects of differing litter sizes on the growth and development of the ovine foetal skeleton. Their model provided a good fit even to measurements such as skull length whose logarithms are not linearly related to the logarithm of foetal weight and which are therefore outside the scope of the conventional allometric model. The model reduces to the Gompertz equation for foetuses which are of standard weight for their age, and to the allometric form for foetuses of any given fixed age, and can be written as :

$$
\ln y=a+b e^{-c t}+d\left(\ln w-\ln w_{t}\right)
$$

where $y$ is a measurement of some foetal component, $t$ is foetal age, $w$ is foetal weight, $w_{t}$ is the standard foetal weight at age $t$ (itself defined by a Gompertz equation relating $w$ to $t)$, and $a, b, c$ and $d$ are constants to be fitted.

Although McDonald ef al. (1977) studied variation in foetal development associated with increases in litter size it seems likely that nutrition was an important mediating factor and the conclusions may be pertinent in the present context. It was shown that there were differential effects on skeletal development, such that lambs which were light at birth were more advanced skeletally than younger foetuses of the same weight. Currently, the same model is being used in the analysis of data on the chemical composition of the foetuses and differential effects are again emerging. It therefore seems highly probable that if sufficient data were available on the weights of tissues, organs and chemical components of the small foetuses arising from under-nutrition of the ewe, then their analysis in terms of the extended Gompertz model would reveal some features to be more developed and others less developed than the overall allometric relationships would suggest. 
Résumé. Huit types d'équation différents qui servent à caractériser la croissance du fœtus ovin pendant les 12 dernières semaines de la gestation sont comparés. On donne la préférence à l'équation de Gompertz parce qu'elle assure des évaluations raisonnables dans le cas de l'extrapolation à 25 jours après l'accouplement et qu'on peut en interpréfer les paramètres en termes biologiques tout à fait faciles à comprendre. Une forme standardisée de l'équation de Gompertz peut être employée pour comparer le cours de la croissance fœtale chez les diverses espèces.

On présente la bibliographie relative aux effets de la nutrition maternelle sur la croissance fotale au début et vers la fin de la gestation, ainsi que pendant la phase intermédiaire. Les résultats font l'objet d'une discussion portant sur des évaluations du poids fœetal et de la vitesse spécifique de croissance à chaque étape, dérivées d'une équation de Gompertz qui se base sur des données fotales.

L'absence d'un modèle convenable représentant le développement fœtal a conduit à un conflit d'opinions lorsqu'il s'agit de déterminer si la sous-alimentation maternelle exerce des influences différentes sur les divers organes et tissus fœtaux. En conclusion on affirme l'existence d'effets différentiels et qu'une extension récente de l'équation de Gompertz, qui embrasse la relation allométrique, fournit un modèle plus clair et d'une application plus généralisée pour caractériser la croissance des éléments fœtaux, que l'équation allométrique toute seule.

\section{References}

ALEXANDER G., 1974. Birth weight of lambs : influences and consequences, 215-239. In ELLIOTT K., KNIGHT J., Size ot birth. Assoc. Sci. Pub., Amsterdam.

CLOETE J. H. L., 1939. Prenatal growth in the Merino sheep. Onderstepoort J. vet. Sci. anim. Ind., 13, 417-558.

CREASY R. K., BARRETT C. T., DE SWIET M., KAHANPAA K. V., RUDOLPH A. M., 1972. Experimental intrauterine growth retardation in the sheep. Am. J. Obsfet. Gynecol., 112, 567-573.

DONEY J. M., SMITH W. F., GUNN R. G., 1976. Effects of post-mating environmental stress or administration of ACTH on early embryonic loss in sheep. J. agric. Sci., Camb., 87, 133-136.

EDEY T. N., 1976. Nutrition and embryo survival in the ewe. Proc. N. Z. Soc. anim. Prod., 36, 231-239.

EL-SHEIKH A. S., HULET C. V., POPE A. L., CASIDA L. E., 1955. The effect of level of feeding on the reproductive capacity of the ewe. J. anim. Sci., 14, 919-929.

EVERITT G. C., 1966. Maternal food consumption and foetal growth in Merino sheep. Proc. Aust. Soc. anim. Prod., 6, 91-101.

EVERITT G. C., 1967. Residual effects of prenatal nutrition on the postnatal performance of Merino sheep. Proc. N. Z. Soc. Anim. Prod., 27, 52-68.

EVERITT G. C., 1968. Prenatal development of uniparous animals with particular reference to the influence of maternal nutrition in sheep, 131-157. In LODGE G. A., LAMMING G. E., Growth and development of mammals, Butterworths, London.

FOOTE W. C., POPE A. L., CHAPMAN A. B., CASIDA L. E., 1959. Reproduction in the yearling ewe as affected by breed and sequence of feeding levels. 2. Effects on foetal development. J. anim. Sci., 18, 463-474.

FOWLER V. R., LIVINGSTONE R. M., 1972. Modern concepts of growth in pigs, 143-161. In COLE D. J. A., Pig production, Butterworths, London.

GRAHAM N. MCC., BLACK J. L., FAICHNEY G. J., ARNOLD G. W., 1976. Simulation of growth and production in sheep - Model $1:$ A computer program to estimate energy and nitrogen utilization, body composition and empty liveweight change, day by day for sheep of any age. Agric. Syst., 1, 113-138.

HUGGETT A. StG., WIDDAS W. F., 1951. The relationship between mammalian foetal weight and conception age. J. Physiol., Lond., 114, 306-317.

HULET C. V., FOOTE W. C., PRICE D. A., 1969. Factors affecting growth of ovine foetuses during early gestation. Anim. Prod., 11, 219-223.

KOONG L. J., GARRETT W. N., RATTRAY P. V., 1975. A description of the dynamics of fetal growth in sheep. J. anim. Sci., 41, 1065-1068. 
LAIRD A K., 1966. Dynamics of embryonic growth. Growth, 30, 263-275.

LAIRD A. K., TYLER S. A., BARTON A. D., 1965. Dynamics of normal growth. Growth, 29, 233-248.

LANGLANDS J. P., SUTHERLAND H. A. M., 1968. An estimate of the nutrients utilized for pregnancy by Merino sheep. Br. J. Nutr., 22, 217-227.

LAWSON R. A. S., 1977. Research applications of embryo transfer in sheep and goats, 72-78. In BETTERIDGE K. J., Embryo transfer in farm animals, Monograph 16, Canada Dept Agric.

MCDONALD I., WENHAM G., ROBINSON J. J., 1977. Studies on reproduction in prolific ewes. 3. The development in size and shape of the foetal skeleton. J. agric. Sci., Camb., 89, 373-391.

MÉNÉZO Y., WINTENBERGER-TORRÈS S., 1976. Free amino acid content of the ewe uterine fluid under various hormonal treatments during early pregnancy. Ann. Biol. anim. Bioch. Biophys., $16,537-543$.

NELSON N. S., COOPER J., 1975. The growing conceptus of the domestic cat. Growth, 39, 435-451.

RATTRAY P. V., GARRETT W. N., EAST N. E., HINMAN N., 1974. Growth, development and composition of the ovine conceplus and mammary gland during pregnancy. J. anim. Sci., 38, 613-626.

RICHARDSON C., HEBERT C. N., 1978. Growth rates and patterns of organs and tissues in the ovine foetus. Br. vet. J., 134, 181-189.

ROBINSON J. J., 1977. The influence of maternal nutrition on ovine foetal growth. Proc. Nutr. Soc., 36, 9-16.

ROBINSON J. J., FORBES T. J., 1968. The effect of protein intake during gestation on ewe and lamb performance. Anim. Prod., 10, 297-309.

ROBINSON J. J., MCDONALD I., FRASER C., CROFTS R. M. J., 1977. Studies on reproduction in prolific ewes. 1. Growth of the products of conception. J. agric. Sci., Camb., 88, 539-552.

ROBINSON W. I., BROWN W., LUCAS I. A. M., 1973. Effects of shelter, exposure and level of feeding over winter on the productivity of Welsh Mountain ewes and lambs. Anim. Prod., 17, 21-32.

RUSSEL A. J. F., CONEY J. M., REID R. L., 1967. Energy requirements of the pregnant ewe. J. agric. Sci., Camb., 68, 359-363.

RUSSEL A. J. F., MAXWELL T. J., SIBBALD A. R., MCDONALD D., 1977. Relationships between energy intake, nutritional state and lamb birth weight in Greyface ewes. J. agric. Sci., Camb., 89, 667-673.

SHEEHAN W., LAWLOR M. J., BATH I. H., 1977. Energy requirements of the pregnant ewe. Ir. J. agric. Res., 16, 233-242.

SHEVAH Y., BLACK W. J. M., LAND R. B., 1975. Differences in feed intake and the performance of Finn $\times$ Dorset ewes during late pregnancy. Anim. Prod., 20, 391-400.

SPEEDY A. W., BLACK W. J. M., FITZSIMONS J., 1978. The effects of autumn management and winter feeding of Border Leicester $\times$ Blackface ewes on the subsequent birthweights of lambs. Anim. Prod., 26, 391-392.

TAYLOR St. C. S., 1965. A relation between mature weight and time taken to mature in mammals. Anim. Prod., 7, 203-220.

THURLEY D. C., REVFEIM K. J. A., WILSON D. A., 1973. Growth of the Romney sheep foetus. N. Z. J. agric. Res., 16,111-114.

TWARDOCK A. R., SYMONDS H. W., SANSOM B. F., 1971. Effect of the number of foetuses present in utero on the transfer rates of calcium and phosphorus across the placenta of the ewe, 139143. In Mineral studies with isotopes in domestic animals, Int. Atomic Energy Agency, Vienna.

VALDEZ ESPINOSA R., ROBINSON J. J., SCOTT D., 1977. The effect of different degrees of food restriction in late pregnancy on nitrogen metabolism in ewes. J. ogric. Sci., Camb., 88, 399-403.

WALLACE L. R., 1948. The growth of lambs before and after birth in relation to the level of nutrition. J. agric. Sci., Camb., 38, 93-153;367-401.

WINTENBERGER-TORRĖS S., 1967. Action de la progestérone et des stéroïdes ovariens sur la segmentation des œufs chez la brebis. Ann. Biol. anim. Bioch. Biophys., 7, 391-406. 